
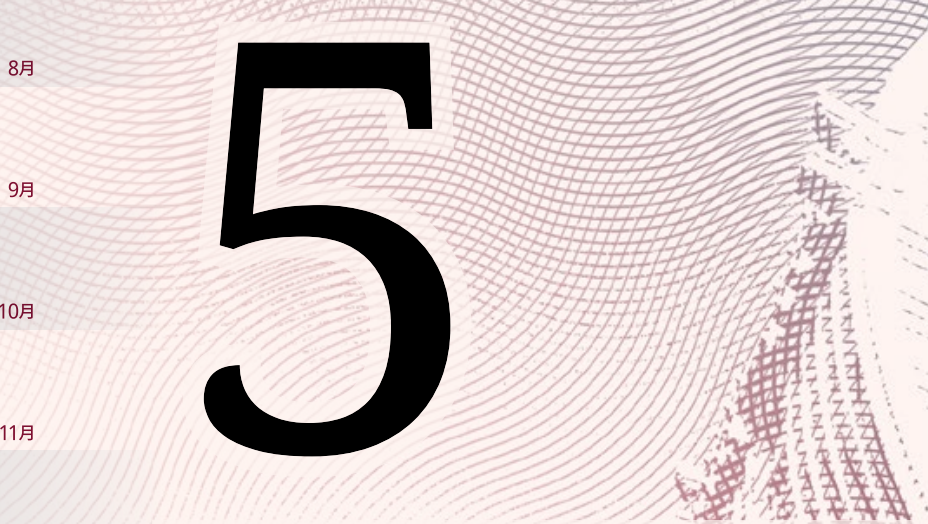

\title{
Gerry Groot
}


IN JANUARY 2017, Chinese security agents entered Hong Kong's Four Seasons Hotel and left with Xiao Jianhua 肖建华. Once described by the New York Times as China's banker for the ruling class, Xiao, a self-made billionaire, ranked thirty-two on the 2016 Hurun Report's China Rich List. It is rumoured that Xiao's clients and connections include members of Xi Jinping's family. Xiao was escorted to the mainland in contravention of Hong Kong law, and his companies have been put up for sale. Of Xiao himself, as of year's end, nothing has been heard. ${ }^{1}$ Xiao was but the latest in a series of such disappearances since $2012 .{ }^{2}$ In China, prosperity is as precarious as it is now ubiquitous.
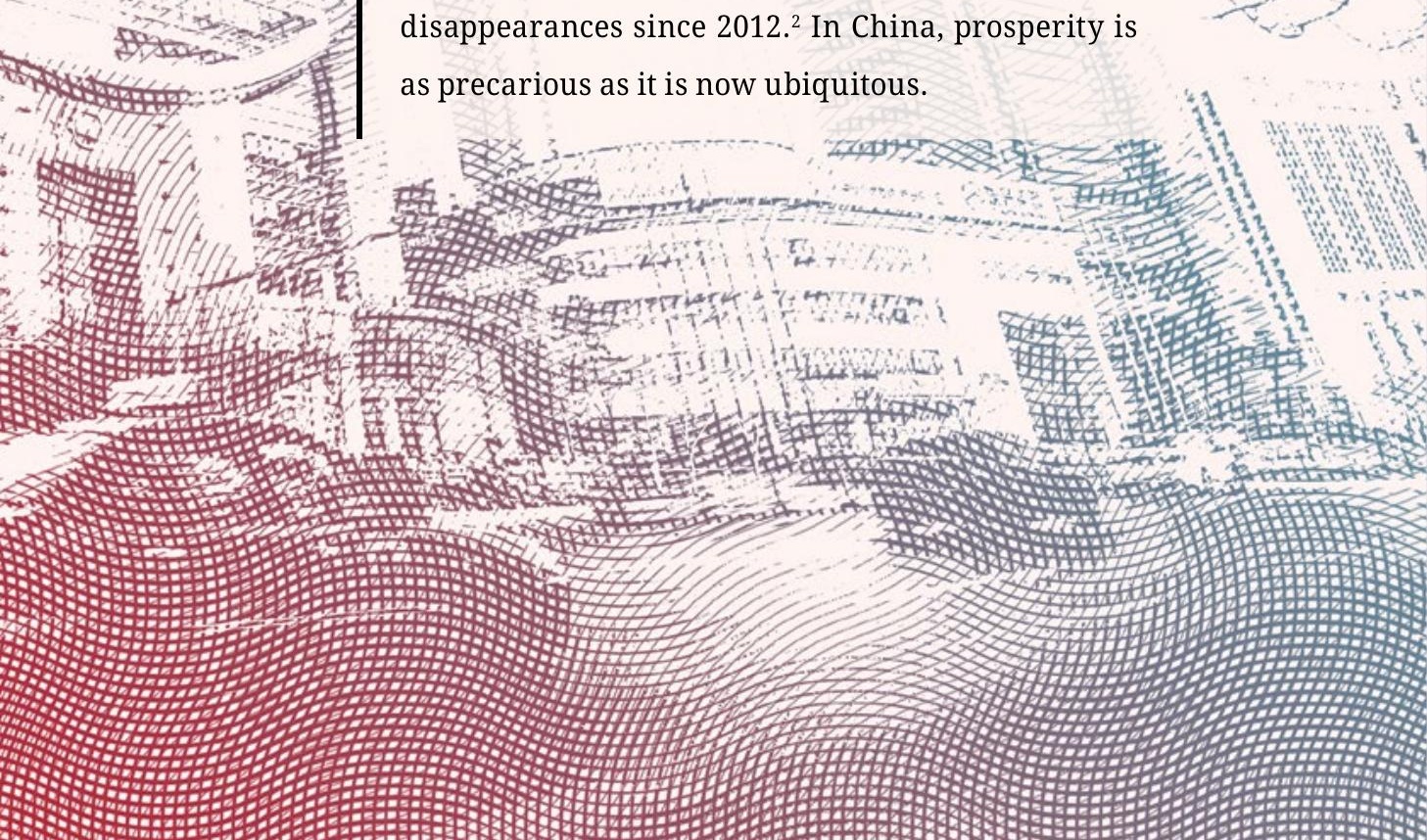


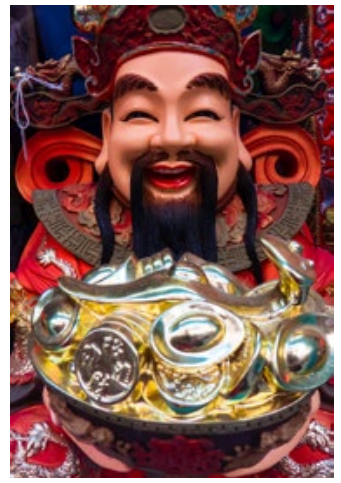

Caishen: The God of Wealth Photo: Simon Crubellier, Flickr
For centuries, many Chinese prayed to Caishen 财神, the God of Wealth, to prosper and preserve their wealth. Fortune was hard won but easily lost, often thanks to arbitrary seizure by rapacious officials in imperial times, through to the Republican Era (19121949), and especially during socialism under Mao (1949-1976). As Xiao's case shows, it remains so. As a result, the wealthy have long seen the need to use their wealth to accrue status, social capital, and political connections to protect themselves.

These features were again reflected in 2017, most notably in the saga of exiled billionaire Guo Wengui 郭文贵, the apparent fall from grace of billionaire Wang Jianlin (see China Story Yearbook 2016: Control, pp.281282), more revelations of offshore holdings in tax havens courtesy of the Paradise Papers, official warnings about 'Grey Rhinos' 灰犀牛 (large overlooked dangers), and debate in Australia, New Zealand, and elsewhere about the influence of other wealthy Chinese linked to the Chinese Communist Party (CCP).

Caishen's re-emergence is a sign that, despite apparent economic success, many still worry that any gains can also easily disappear. Complicating matters are lingering Confucian beliefs that business is ipso facto corrupt and conducted by 'small people' 小人, not people of virtue 君子 - a mindset reinforced by the Mao-led communist revolution (1949-1976) to eliminate capitalism and 'selfish' economic behaviour. Despite the post1978 economic reforms, this suspicion has never quite disappeared and has been compounded by the knowledge that much wealth today is tainted. The revelations of the ongoing anti-corruption campaign confirm such suspicions. China's wealthy are caught between popular admiration of their material success and the possibility of sudden official moral or political condemnation - or worse, as Xiao Jianhua discovered first hand. 


\section{From Ming to Mao}

Under the Ming (1368-1644) and especially the Qing dynasties (16441911), officials encouraged small enterprises but were wary of the rich who might cause unrest by exploiting the weak or concentrating wealth. ${ }^{3}$ The wealthy therefore sought social legitimacy through philanthropy including building temples, schools, roads and the like. Because Chinese relied then as now, on personal relationships rather than a clear system of laws 靠人不靠治, charity and public works were ways of being seen as virtuous by society and acquiring friends in high places.

After establishing the People's Republic of China (PRC) in October 1949, the CCP under Mao set about building autarkic communism, including by 'encouraging' the wealthy to socialise their assets by handing them over to cooperatives or by confiscating them. All private business, private property, and 'selfish' profit were to be eliminated. The so-called capitalists then underwent 'thought reform', in order to become proletarian in their thinking. However, to rebuild war-ravaged industry, some businessmen were allowed continued prominence as part of the AllChina Federation of Industry and Commerce (ACFIC). The China Democratic National Construction Association or Min Jian, represented such people in the Chinese People's Political Consultative Conference (CPPCC) as one of China's eight 'democratic parties' 民主党派 under the control of the United Front Work Department (UFWD). A key CCP department, the UFWD was responsible for liaising with and integrating or eliminating allies including 'capitalists'. ${ }^{4}$

The Three-Anti (1951) and the Five-Anti (1952) campaigns, meanwhile targetted alleged corruption, bribery, tax evasion, cheating on government contracts, and the stealing of state secrets. Many suffered in labour camps and/or were driven to suicide while business was again discredited.

Among the few to escape were 'red capitalists' such as Rong Yiren 㭉毅仁, an heir to a business conglomerate who remained in Shanghai after other family had fled. The ACFIC and Min Jian promoted Rong and 


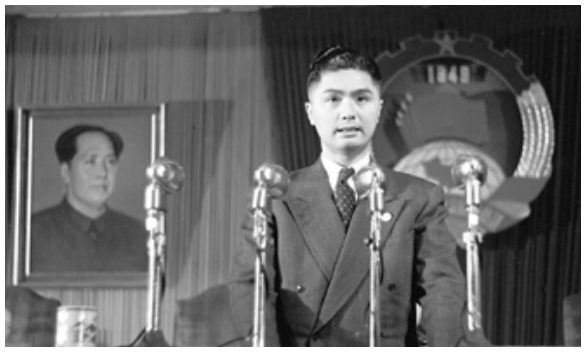

Rong Yiren, 1951

Source: Wikimedia Commons others as role models. In 1951, he reputedly tried to formally join the CCP but was told by Mayor Chen Yi 陈毅 that he would be more useful as a non-member. Rong was protected during the Cultural Revolution by Premier Zhou Enlai 周 恩来 - a sure sign of his privi-

leged status, and was quickly 'rehabilitated' in the Deng era. He did secretly join the CCP in 1985, although this was only revealed after his death. ${ }^{5}$ As a reward for his devotion, in 1993 Rong was appointed a vice-president of China. Not long after, his son, Larry Yung 㭉智健, who had moved to in Hong Kong in the early 1990s, became chairman of CITIC Pacific, an offshoot of CITIC (China International Trust Investment Corporation), a semistate-owned investment company that Rong helped found in 1979 with the support of the UFWD, ACFIC, and Min Jian. ${ }^{6}$ The boundaries between the Party and business were deliberately obscured but with the 'private' aspect now emphasised. Though there is no clear current equivalent of Rong Yiren, the very personable Alibaba Billionaire, 'Jack' Yun Ma 马云, is perhaps the closest contender. Though Ma is only a member of the Zhejiang provincial CPPCC, given his increasing prominence, it may not be long before he too is promoted to the central-level CPPCC.

The post-Mao economic reforms allowed a revival of fortunes for surviving 1940s business people, with the UFWD encouraging them to establish new enterprises and get once-frowned-upon 'patriotic' friends and relatives abroad to invest in their 'ancestral land' 祖国. This United Front work encouraging overseas Chinese investment became a major factor in China's development. It also resulted in a new generation of wealthy Chinese, both local and overseas, with close CCP connections, often reflected by prestigious and protective appointments to the various levels of the CPPCC. 


\section{IN THE NAME OF THE PEOPLE,}

by Yang Qin

The anti-corruption television drama In the Name of the People 人民的名义 was a massive hit in 2017, gripping audiences from the broadcast of the first episode in March. The fifty-two-episode drama, based on a novel by Zhou Meisen 周梅森, had captured a record ten per cent average of

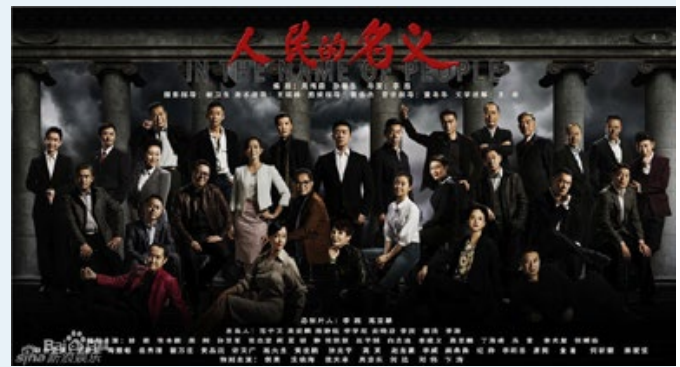

Promotional material for In the Name of the People Source: Baidu Chinese viewers nationally, racking up over 7.7 billion views on just one licensed platform, iQiyi, alone.

After a decade of strict censorship of social and reality television dramas by the State Administration of Press, Publication, Radio, Film, and Television, In the Name of the People struck many as tremendously bold, even if it was 'on message' with President Xi Jinping's sweeping anti-corruption campaign; some have even compared it with Netflix's House of Cards.

The Supreme People's Procuratorate commissioned the series, which also lists among its producers the Jiangsu Provincial Party Committee and the Central Military Commission. Hunan Television, a leading broadcaster of television entertainment programs and the primary online distributor of this drama, PPTV, had made a good bet on the show despite initial funding problems and low expectations for success.

The story begins when a director at the central Ministry of Land and Resources - a position famously prone to corruption in the bureaucracy - is, despite a carefully cultivated reputation for austerity, found to have in his suburban villa huge amounts of cash that he has amassed through bribery. The investigation is headed by Hou Liangping, a determined young official from the Supreme People's Procuratorate. The director's downfall — kneeling and weeping for mercy before the young official - is just the beginning of the young investigator's campaign to uncover the truth behind corrupt goings-on within a state-owned enterprise (SOE). As the story unfolds, Hou uncovers entangled relationships involving local officials past and present in the fictive province of Handong. There are scenes of sexual bribery, nepotism, heavying by gangsters in labour disputes, and other abuses of power by government officials.

The unprecedented revelation of corruption behind the scenes has evoked passionate responses from audiences, with the series becoming a major topic of conversation for old and young in the early months of 2017. A sea of online commentary from China's lively netizen community ranged from casual gossip about love, women, and marriage, to more serious ones of social stratum, bureaucracy, and governance. There was also quite a bit of liveliness and humour, with some writing funny songs and creating emojis based on characters in the show, and making stars of the actors they nicknamed the 'Handong Boys'.

In November 2017, a lawsuit ensured that this drama remained in the limelight. An accusation was made that one of its main plots was plagiarised from a former journalist's publication in 2010, as the two share similar scenes of worker protests, government regulation, and gangster interference surrounding the selling and reform of an SOE. The scriptwriter for In the Name of the People denied the accusation, making the point that this particular plot is typical of Chinese enterprise reform during past decades. While the outcome of the lawsuit is still pending (at the time of publication), it's hard to argue with this point. 


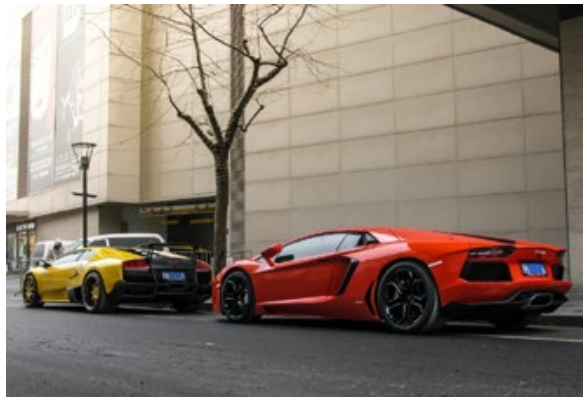

Lamborghinis parked in a street in Shanghai

Photo: Joshua, Flickr
In the countryside, the revival of rural markets in the late-1970s meant that farmers were again allowed to sell produce for profit. Rural entrepreneurs soon emerged, many of whom had been landlords or successful farmers before losing everything to revolutionary land redistribution in the

early 1950s. They traded in food and raw materials, then often moved into transport, food processing, and small-scale manufacturing. These changes gave rise to so-called 'explosive wealth' 爆发户 before much change was seen elsewhere.

In towns and cities where workers and government employees were suffering under inflation for the first time since 1950, there was considerable envy. Among the resentful were university students and staff whose protests, including against the rising corruption accompanying rising wealth, culminated in the Tiananmen protests of 1989.

In the cities too, there was a rise in entrepreneurship. Many, including those who could not find work in regular state work units, or danwei 单位, for reasons including negative political assessments in their personal files, became individual entrepreneurs - peddlers and tradespeople. Though often despised as profiteers, many of these entrepreneurs supported the students protesting in 1989.

The Beijing Massacre of 4 June 1989 and subsequent political suppression caused many business people to worry that the Party was returning to its Maoist roots, and those who could fled abroad.

In part due to the 1989 protests, the Party also became acutely aware of the potential danger of a financially independent middle class and new rich. Both Western democratic theory and Marxism hold that propertied classes will demand electoral democracy to protect their interests and 
property. To forestall this, the CCP raised the status of the ACFIC and related United Front work. In 2002, Party General Secretary Jiang Zemin 江泽 民, through his theory of the 'Three Represents' 三个代表, claimed that the CCP also represents China's 'advanced social productive forces' and for the first time ever invited business people to join the Party.

In 2007, the National Peoples' Congress (NPC) ratified constitutional changes recognising a right to private property. However, any comparisons to Western property rights and assumptions about business obscure these unique relationships between history, the Party-state system, success, United Front Work, and fear of loss. These factors also help explain the actions of some of China's wealthy, at home and abroad.

\section{Today's Billionaires and Power}

The US Congress has no billionaires. China's National People's Congress has some one hundred of them. With 609 in total as of 2017, China has more billionaires than America. ${ }^{7}$ And their wealth is growing faster than the economy overall. ${ }^{8}$

China's rich are amongst the strongest supporters of the Party-state system in large part because their prosperity owes so much to it, despite their need to curry favour to protect themselves. While Xiao Jianhua's fate is still unclear, his extra-legal abduction is a good illustration that wealth alone is not enough protection.

\section{The Extraordinary Case of Guo Wengui}

The most dramatic example of these complex relations between wealth and the Party-state in 2017 has undoubtedly been the case of real estate billionaire Guo Wengui 郭文贵, also known as Miles Kwok, a conspicuous member of Donald Trump's Mar-a-Lago Club. Guo fled China in 2014 after Caixin magazine investigated his rise and called him a power 


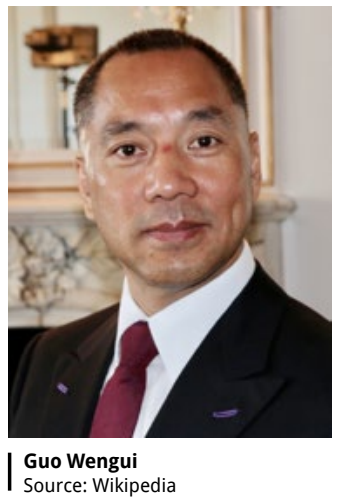

hunter' 权力猎手 for his corruption and shady links with officials. ${ }^{9}$ Once in exile, Guo made an escalating series of claims about corruption by others, particularly Wang Qishan 王岐山, the Secretary of the CCP's key anti-corruption body, the Central Commission for Discipline Inspection. Guo, who paints himself as a patriotic whistleblower, has insisted that he is only trying to support Party General Secretary Xi Jinping's anti-corruption campaign.

Soon after Guo began alleging corruption in high places, the CCP retaliated by revealing the arrest of his close associate, Ma Jian 马建, formerly a vice-minister of state security. In a televised confession, Ma alleged that since 2008, he worked with Guo to spy on, interfere with, and even jail Guo's competitors in an 'alliance of shared interests'. In some cases, Ma himself rang competitors to emphasise Guo's connections. In return, Guo allegedly paid Ma some sixty million yuan in properties, cash, and gifts. ${ }^{10}$ Most shockingly, Ma's confession demonstrated that even the most sensitive parts of the Party-state system could be bought, if the price was right.

Guo's collusion with Ma was only the most dramatic in a long list of activities in which Guo worked with officials to get rich. Jailed for fraud in the early 1990s, Guo became a real estate entrepreneur in Zhengzhou, where he cultivated close relations with local Party Secretary, Wang Youjie 王有杰. This allowed Guo to acquire prime real estate near the railway station for his first skyscraper and in turn he appointed Wang's son to his company board.

In anticipation of the 2008 Beijing Olympics, Guo then acquired land near the proposed site but soon ran into serious planning and payment disputes with officials. As a result, the land was resumed by Beijing ViceMayor Liu Zhihua 刘志华. In retaliation, and using his security apparatus 
connections, Guo then entrapped Liu with a sex tape. After Liu was arrested in 2006, Guo was able to regain the land and built his famous Pangu Plaza. He subsequently used rooms in its hotel to tape officials' dalliances with prostitutes to blackmail them. He also became friends with Ling Jihua 令计划, subsequently head of the UFWD itself, until a car crash involving Ling's son (see China Story Yearbook 2013: Civilising China, pp.24-25) exposed Ling's web of corruption.

Guo's membership of Mar-a-Lago fits his pattern of 'talking flattery to power'. In October, he even met Steve Bannon, Trump's former adviser - who had met secretly with Wang Qishan in September. ${ }^{11}$ As in China, Guo has invested in American connections to power and legitimacy while pursuing his multipronged media campaign aimed (unsuccessfully) at influencing the Nineteenth Party Congress, presumably to get himself off the corruption charges he was facing at home. After all, he might be forgiven if he is useful enough or if others he has cultivated or blackmailed in the past rise to power.

Using Twitter, video streaming, radio and press interviews, Guo went all out to present himself as a patriot ('My only goal is to save China'), producing a series of often incredible claims and documents purporting to prove elite corruption, notably by Wang Qishan. Though excluding $\mathrm{Xi}$ Jinping, Guo denounced numerous other leaders as 'a tiny group of Mafioso'. ${ }^{12}$ For much of the year he seemed to be attempting to both qualify for asylum in America and win the support of Xi himself (unlikely). By year's end, he was calling for regime change, actions which may make any claim for asylum more creditable. ${ }^{13}$

The CCP took unprecedented measures to silence Guo. It apparently managed to have a live Voice of America (VOA) radio interview with him cut short - a clear compromise to the broadcaster's independence. Some VOA staff were suspended as a result. ${ }^{14}$ In China, he was roundly denounced, and in December senior employees, including one of his brothers, were found guilty of destroying accounting records. ${ }^{15}$ 


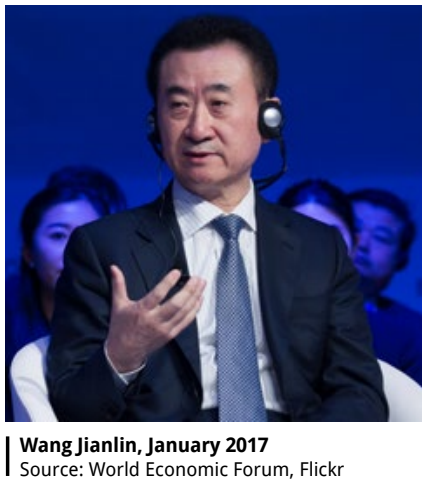

Source: World Economic Forum, Flickr
Numerous Chinese nationals launched court cases against Guo. Among them was a vice-minister of housing, who sued him for \$US10 million for alleging that she traded in sexual favours and was corrupt; ${ }^{16} \mathrm{a}$ hedge fund for US\$88 million for defaulting on debts and seeking a restraint over his US\$68 million New York apartment; ${ }^{17}$ and actress Fan Bingbing 范冰冰, who threatened to sue over his claims that she had slept with Wang Qishan. ${ }^{18}$

Perhaps most dramatic were the allegations of rape levelled against Guo by a former personal assistant. This became the basis for a second Interpol red notice warrant for him. ${ }^{19}$ The first, in April, was instigated by Beijing alleging corruption. Since 2016, Interpol has been headed by Chinese Vice-Minister of Public Security, Meng Hongwei 孟宏伟. A day after alleged Chinese interference saw his talk to Washington's Hudson Institute cancelled, Guo claimed Beijing had 25,000 spies in the US. Guo's claims had some credence because of his association with Ma Jian, once responsible for aspects of counter intelligence. ${ }^{20}$

Guo also ended up being suspended from social media platforms: his Twitter account was suspended briefly in April following a similar interruption to his Facebook account, ${ }^{21}$ while in October his YouTube account was also suspended. ${ }^{22}$ These incidents vividly demonstrate the increasing ability of the CCP to directly interfere with social media worldwide - despite Twitter being banned in China. That Guo has 466,000 Twitter followers makes him even more of a worry, and the CCP's desire to increase ideological and United Front Work abroad even more pressing.

Guo's case is the most dramatic exposé of official-private collusion since the Bo Xilai-Wang Lijun case of 2012 (see the China Yearbook 2012: 
Red Rising, Red Eclipse) and again highlights just how deep and pernicious the relationships between power, corruption, and wealth can be in a Partystate system.

One way to keep any gains is, of course, to send it abroad. It was not clear how Guo still had access to money after fleeing China. In November 2017, however, the International Consortium of Investigative Journalists revealed a second set of leaks about tax havens - the Paradise Papers. In 2016, the Panama Papers had revealed that Li Xiaolin 李小琳, the daughter of former leader Li Peng 李鹏, and even Xi Jinping’s brother-in-law, Deng Jiahui 邓家贵, had been using tax havens to stash their wealth. Some nine companies related to Wang Jianlin 王健林, the real estate billionaire of Wanda fame who came to Western attention in 2016 for buying up theatres and studios in the US (see the China Story Yearbook 2016: Control, pp.281-282), used tax havens in the Bahamas, the Virgin Islands, and Luxembourg. ${ }^{23}$ There are likely to be many more wealthy Chinese seeking to hide their assets this way.

\section{If You Can't Beat "em...}

If not for the Caixin revelations, there is a chance that Guo would have sought, or been sought out, to join the CCP, be elected to an NPC at some level, or selected by the UFWD as a representative in the CPPCC. The status afforded by these bodies was reflected when, in March, the Liaoning NPC expelled forty-five members, nearly all businessmen, for having purchased their seats. However, the situation only came to light when Beijing's favoured candidates failed to get elected. ${ }^{24}$

This keenness to be seen to be a part of the Party-state is understandable. Proximity to power means privileged access to decision-makers, licences, bank loans, and higher level connections, and especially to scarce real estate as Guo's case reflects. At its best, this creates a virtuous cycle; at its worst, a vicious one. 


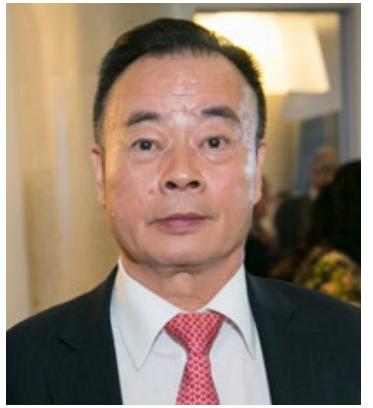

Dr Chau Chak Wing

Source: UTS Advancement, Flickr
Aspects of positive symbiotic businessParty relationships are evident with some of the Chinese billionaires who have come to prominence in Australia. In the China Story Yearbook 2016, we discussed the role of Huang Xiangmo 黄向墨, his donations to Australian political parties and his role in United Front activities. On 6 June 2017, a joint investigation by the ABC's Four Corners program and Fairfax screened, called 'Power and Influence: The Hard Edge of China's Soft Pow-

er', about United Front-linked money and Australian politics. ${ }^{25}$ One ABC report revealed how almost six million dollars had gone to politicians of both major parties. ${ }^{26}$ In this and subsequent investigations and reports, notably about the Australian Council for the Promotion of Peaceful Reunification, headed by Huang, there were a number of revelations about UFWD work in Australia. ${ }^{27}$ The Council's front page even links directly to UFWD-linked organisations.

Another prominent businessman and philanthropist, Chau Chakwing 周泽荣, who is an ACPRRC member as well as an Australian citizen of twenty years, came to public attention in 2017, in part because of his connections with Huang and subsequently because of his decision to sue the $\mathrm{ABC}$ and Fairfax for defamation in relation to their revelations. In a later interview, he denied any wrongdoing and, most pertinently, declared, 'For the record, I have never been a member of the Chinese Communist Party and I have never been a member of an advisory group called the People's Political Consultative Conference'. He went on to say that, 'As to the entity referred to by the ABC as the "United Front Work Department”, I have no idea what this is'. ${ }^{28}$

Chau's rise to wealth and power, however, seems intimately connected to his relations with the UFWD in his home province of Guangdong, 
and in particular the Chaozhou region and his city of birth, Shantou. Within Guangdong, Chau is officially lauded as an outstanding overseas Chinese entrepreneur. According to the Shantou UFWD, Chau migrated to Hong Kong in the 1970s and then to Australia, returning to China in 1988. There he became involved in real estate, food, and media. The Department also stresses his contributions to charity, including building schools. His appointments include being a deputy chair of the China Federation of Returned Overseas Chinese Association. The photos of Chau include ones with former leader $\mathrm{Hu}$ Jintao and former Australian prime minister, Kevin Rudd. ${ }^{29}$

Chau's return to Shantou was timely, coming when the UFWD was actively wooing overseas Chinese investors to contribute their money and talents to building up their ancestral land, and profit at the same time. In July 2007, at Guangdong's Oriental Hotel and in the presence of the Provincial Head of the UFWD, Zhou Zhenlong 周镇宏, Chau launched the Guangdong Overseas Chinese Commercial Investor Industry Association. Its precursor association launched in 1990, said Chau, had been the earliest such organisation in China and had played a major role in attracting investment under the auspices of the Overseas Chinese Affairs Office (the government face of the UFWD).$^{30}$ Chau's closeness to the UFWD, then, is long-standing.

On 30 November, Chau's efforts to court influential non-Chinese former leaders and people of influence by hosting meetings to discuss China's international relations reached its apogee. Guests at his Imperial Springs International Forum, held at Chau's palatial Imperial Springs Hotel in Guangdong, included former United Nations head, Ban Ki-moon and former New Zealand prime minister, Jenny Shipley. Their presence and discussions of China's international relations was rewarded in dramatic style when Chau and his guests were invited to Beijing to meet Xi Jinping himself. ${ }^{31} \mathrm{~A}$ more ringing endorsement of Chau's influence can hardly be imagined. 


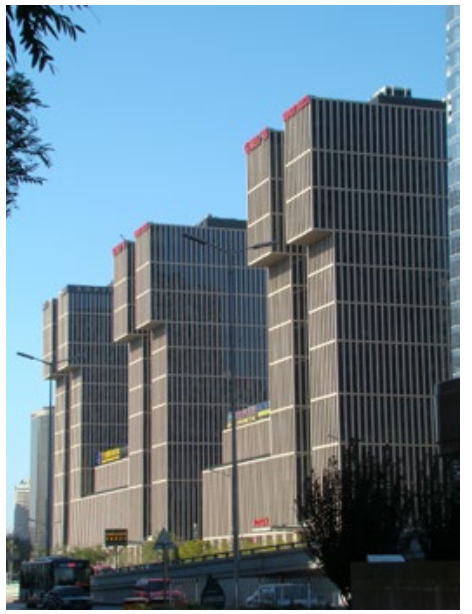

Beijing Wanda Plaza (headquarters for Wanda Group and Wanda Cinemas)

Source: Dennis Deng, Flickr

\section{The Fall of a Grey Rhino}

What the Party giveth, it can also take away. One real estate billionaire with very good connections to the Party, Wang Jianlin of Wanda, mentioned above in connection with the tax havens, had been able to access loans large enough to bid for Hollywood studios and cinema chains at least partly because the purchases supported Chinese soft power, in particular an increase in Chinese influence over international media. Many of the deals hyped up in 2016, however, fell through in 2017..$^{32}$

Then, in July, Wanda was one of a number of large private firms with good connections that were criticised in the People's Daily as 'grey rhinos' 灰犀牛. ${ }^{33}$ The paper explained 'A grey rhino is massive, and responds slowly - you can see it clearly in the distance, but if it charges you, it will catch you off guard and gore you'. ${ }^{34}$ Today's rhinos are big companies now struggling under huge debts and therefore posing an economic threat. Responsibility for these loans, rather than being sheeted home to the officials who approved them, was placed on the companies themselves. By the end of August, there were repeated rumours, subsequently refuted, that Wang was under suspicion for corruption and unable to leave China. While Wang remains free, by the end of 2017, he had gone very quiet.

\section{Conclusion}

While wealth in China brings many benefits, it brings only limited protection if it is not also supported by officialdom, the higher the better. 
It should not be surprising then, if Chinese business people abroad also assume that similar situations apply in foreign environments and act accordingly by seeking access and possible protection from the local political elites. Such behaviours though, make it very difficult for others to judge intentions and where the boundaries between private initiative and Party-state influence might lie, if indeed there are any. Cases like that of Guo Wengui make such judgements even harder. The ramifications of these dilemmas are only just beginning to make themselves felt in Australia and elsewhere. 
This text is taken from China Story Yearbook 2017: Prosperity, edited by Jane Golley and Linda Jaivin, published 2018 by ANU Press, The Australian National University, Canberra, Australia.

doi.org/10.22459/CSY.04.2018.05 